\title{
VALIDITAS BAHAN AJAR KURIKULUM PEMBELAJARAN UNTUK PENDIDIKAN GURU SEKOLAH DASAR
}

\author{
Isnaini Wulandari ${ }^{1}$, Ndaru Mukti Oktaviani ${ }^{2}$ \\ 1,2 Universitas Kuningan, Kuningan, Indonesia \\ ${ }^{1}$ isnaini.wulandari@uniku.ac.id
}

\begin{abstract}
The purpose of this study was to determine the validity of teaching materials for the learning curriculum for primary school teacher education. This research is included in research and development. Research and development procedures carried out in the development of learning curriculum teaching materials for primary school teacher education refer to Borg and Gall's development steps, namely 1) gathering information and preliminary research, 2) planning, 3) developing initial product forms, 4) conducting limited trial of the initial product to produce the main product, 5) revising the main product, 6) testing the main product, 7) revising the main product to produce the final product, 8) conducting field trials of the final product, 9) conducting revisions to the final product, and 10) disseminating and implementing the product. The ten steps are grouped into three steps, namely a preliminary study, development, and testing and dissemination. This article only focuses on the validity of content which is validated by experts. The experts involved are material experts and media experts. The content validity analysis technique used the Aiken's $V$ index. Based on the results of Aiken's $V$ analysis, a score of 0.918 was obtained, and it was interpreted as a fairly high coefficient because the score was between 0 and 1.00. So that the learning curriculum teaching materials for primary school teacher education are in the valid category.
\end{abstract}

Keywords: aiken's v; content validity; curriculum of learning; learning material

\begin{abstract}
Abstrak
Tujuan dari penelitian ini adalah untuk menentukan validitas bahan ajar ajar kurikulum pembelajaran untuk pendidikan guru sekolah dasar. Jenis penelitian ini termasuk dalam penelitian dan pengembangan. Prosedur penelitian dan pengembangan yang dilakukan dalam pengembangan bahan ajar kurikulum pembelajaran untuk pendidikan guru sekolah dasar mengacu pada langkah-langkah pengembangan Borg and Gall yaitu 1) mengumpulkan informasi dan penelitian pendahuluan, 2) melakukan perencanaan, 3) mengembangkan bentuk produk awal ,4) melakukan uji coba terbatas produk awal untuk menghasilkan produk utama, 5) melakukan revisi terhadap produk utama, 6) melakukan uji coba produk utama, 7) melakukan revisi terhadap produk utama untuk menghasilkan produk akhir, 8) melakukan uji coba lapangan produk final, 9) melakukan revisi terhadap produk final, dan 10) mendiseminasi dan mengimplementasikan produk. Kesepuluh langkah tersebut dikelompokkan kedalam tiga langkah yaitu studi pendahuluan, pengembangan, serta pengujian dan diseminasi. Artikel ini hanya fokus pada validitas isi yang divalidasi oleh ahli. Ahli yang dilibatkan adalah ahli materi dan ahli media. Teknik analisis validitas isi menggunakan indeks Aiken's V. Berdasarkan hasil analisis Aiken's V diperoleh skor 0,918, dan diinterpretasikan sebagai koefisien yang cukup tinggi karena skor tersebut ada diantara 0 sampai 1,00. Sehingga bahan ajar kurikulum pembelajaran untuk pendidikan guru sekolah dasar dalam kategori valid.
\end{abstract}

Kata Kunci: aiken's v; bahan ajar; kurikulum pembelajaran; validitas

\begin{tabular}{llll}
\hline Received & $: 2020-10-13$ & Approved & $: 2021-01-02$ \\
Reviesed & $: 2020-11-30$ & Published & $: 2021-01-31$ \\
\hline
\end{tabular}

Jurnal Cakrawala Pendas is licensed under a Creative Commons Attribution-

ShareAlike 4.0 International License. 


\section{Pendahuluan}

Kurikulum pada proses pendidikan memiliki peranan strategis dalam menentukan cara atau langkah untuk mencapai tujuan Pendidikan (Oktaviani \& Wulandari, 2019). Hal ini dikarenakan dalam kurikulum terdapat seluruh garis besar kegiatan pendidikan mulai dari tujuan, proses pembelajaran, kompetensi yang harus dicapai oleh peserta didik, hingga evaluasi. Sehingga kurikulum dapat dikatakan sebagai kerangka utama yang akan dijadikan sebagai patokan dalam menjalankan proses pendidikan. Melihat pentingnya kedudukan kurikulum maka seorang pendidik harus paham mengenai segala seluk beluk kurikulum. Merespon kebutuhan tersebut pada perguruan tinggi yang memiliki program studi pendidikan, mata kuliah kurikulum pembelajaran menjadi mata kuliah yang wajib dikuasai oleh mahasiswa. Hal ini dilakukan agar para pendidik di masa yang akan datang mampu menerapkan kurikulum secara tepat, begitu juga pada program studi PGSD.

Pada mata kuliah kurikulum pembelajaran diperlukan bahan ajar yang memadai untuk menunjang proses pembelajaran. Sebagaimana kita ketahui bahwa bahan ajar merupakan materi yang disajikan dalam buku pendidikan berdasarkan kompetensi dasar disesuaikan dengan tujuan yang akan dicapai. Secara lebih lanjut bahan ajar dapat dikatakan sebagai perangkat pembelajaran yang berisi kompetensi dan materi pembelajaran yang disusun secara sistematis dan runtut untuk mencapai tujuan/kompetensi pembelajaran yang telah direncanakan (Ulfah \& Jumaiyah, 2018). Oleh karena itu, bahan ajar sebaiknya disusun dengan sitematis, artinya bahan ajar yang baik hendaknya memiliki sintak penyusunan yang disesuaikan dengan tujuan dari dibentuknya bahan ajar tersebut. Hal ini dikarenakan melalui bahan ajar yang berkualitas dapat membantu pengajar untuk menyampaikan materi pembelajaran secara maksimal (Kurniawan et al., 2018).

Bahan ajar mempunyai fungsi yang sangat strategis di dalam proses pembelajaran. Berdasarkan fungsinya bahan ajar dibagi menjadi dua (Prastowo, 2013) yaitu fungsi bahan ajar bagi pendidik dan fungsi bahan ajar bagi peserta didik. Secara lebih lanjut fungsi bahan ajar bagi pendidik terbagi menjadi menjadi empat. Pertama bahan ajar dapat digunakan untuk menghemat waktu pendidik dalam mengajar. Kedua bahan ajar dapat mengubah peran pendidik dari seorang pengajar menjadi seorang fasilitator sehingga meningkatkan proses pembelajaran menjadi lebih efektif dan interaktif. Ketiga bahan ajar dapat digunakan sebagai pedoman bagi pendidik yang akan mengarahkan semua aktifitas dalam proses pembelajaran, hal ini dikarenakan bahan ajar merupakan substansi kompetensi yang semestinya diajarkan kepada peserta didik. Keempat bahan ajar bagi pendidik dapat digunakan sebagai alat evaluasi pencapaian atau penguasaan hasil pembelajaran.

Selain fungsi bagi pendidik bahan ajar juga memiliki lima fungsi bagi peserta didik. Pertama melalui bahan ajar peserta didik dapat belajar tanpa harus ada pendidik atau teman peserta didik yang lain. Kedua peserta didik dapat belajar kapan saja dan dimana saja sehingga proses belajar dapat disesuaikan dengan kecepatan masing-masing individu. Ketiga peserta didik juga dapat belajar sesuai dengan urutan yang dipilihnya sendiri. Keempat bahan ajar akan mampu membantu peserta didik untuk menjadi pelajar yang mandiri. Kelima bahan ajar dapat dijadikan sebagai pedoman peserta didik dalam semua aktifitasnya pada proses pembelajaran, karena bahan ajar berisi merupakan substansi kompetensi yang seharusnya dipelajari atau dikuasai.

Berdasarkan fungsi bahan ajar yang telah dibahas di atas maka dapat dikatakan bahwa bahan ajar sangat membantu peserta didik dalam menguasai kompetensi yang telah ditetapkan. Begitu pula fungsi bahan ajar pada level perguruan tinggi. Bahan ajar juga 
memiliki peranan penting dalam membantu mahasiswa menguasai kompetensi yang harus dicapai. Hal ini dikarenakan tanpa bahan ajar yang memadai, mahasiswa akan sulit menyesuaikan diri dalam proses belajar, apalagi jika dosen menjelaskan materi dengan cepat dan kurang jelas (Purwati \& Suhirman, 2017). Dengan demikian, mahasiwa memerlukan bahan ajar untuk menelusuri kembali apa yang telah disampaikan oleh dosennya.

Namun pada kenyataannya terdapat keterbatasan bahan ajar mata kuliah kurikulum pembelajaran untuk program studi PGSD. Keterbatasan bahan ajar mata kuliah kurikulum pembelajaran ini lebih pada konten bahan ajar. Hal ini sesuai dengan pendapat Buyung (2018) yang menyatakan bahwa bahan ajar pada perguruan tinggi masih mengkonpilasi sumber yang ada, dimana referensi yang digunakan masih terbitan lama sehingga ada beberapa materi yang kurang sesuai dengan keadaan pada saat ini. Secara lebih lanjut melalui observasi secara menyeluruh pada bahan ajar mata kuliah kurikulum pembelajaran untuk program studi PGSD yang tersedia, pada konten isinya belum bersifat kontekstual. Selain itu masih banyak materi yang pada dasarnya membutuhkan ilustrasi namun tidak ditampilkan dalam bahan ajar. Kondisi tersebut tentunya membuat mahasiswa kesulitan untuk menguasai kompetensi yang dibutuhkan ketika nantinya mereka menjadi seorang pendidik. Oleh karena itu perlu dikembangkan bahan ajar mata kuliah kurikulum pembelajaran yang memadai. Melalui pengembangan bahan ajar diharapkan akan dapat menunjang pencapaian kompetensi (Devi, 2009).

Pengembangan bahan ajar kurikulum pembelajaran untuk pendidikan guru sekolah dasar pada pelaksanaannya membutuhkan uji kelayakan. Hal ini dilakukan untuk memastikan bahwa produk bahan ajar yang dihasilkan layak digunakan. Salah satu cara untuk menguji kelayakan produk dapat ditempuh dengan menguji validitas isi. Validitas isi adalah sejauh mana unsur-unsur dalam instrumen penilaian dapat relevan serta mewakili konsep yang direncanakan untuk disesuaikan dengan tujuan penilaian tertentu (Haynes et al., 1995).

Secara lebih lanjut validitas isi merupakan salah satu jenis validitas yang paling umum digunakan untuk mengetahui keandalan suatu instrumen yang dibuat oleh peneliti pada tahap awal pengembangan instrumen (Vakili et al., 2018). Dengan kata lain tujuan validitas isi adalah mengurangi kesalahan pembuatan instrumen dan meningkatkan kemungkinan diperolehnya indeks validitas konstruk dalam studi lanjutan. Untuk menerapkan validitas isi terdapat beberapa langkah sebagai berikut (1) Melakukan tinjauan literatur secara lengkap untuk dapat mengambil inti dari item terkait, (2) Validitas isi meninjau secara umum pada setiap item yang dinilai menggunakan 3 skala yaitu tidak perlu, berguna tetapi tidak penting dan penting, (3) Peninjauan pada validitas isi harus dilakukan dengan mengirimkan item pada ahli pada bidang yang diteliti, (4) Rasio validitas isi (CVR) kemudian dihitung untuk setiap item dengan menggunakan metode Lawshe dan (5) Item yang tidak signifikan pada level kritis dieliminasi. Mengikuti tingkat kritis yang dijelaskan pada metode Lawshe (Taherdoost, 2016).

Terdapat beberapa cara dalam mengevaluasi validitas isi salah satunya adalah Koefisien validitas isi - Aiken's V. Validasi isi menggunakan Aiken V mampu memberikan gambaran penilaian pada alat ukur yang mengukur aspek kognitif dan non-kognitif. Fungsi Aiken's V dalam penelitian pengembangan bahan ajar kurikulum pembelajaran untuk pendidikan guru sekolah dasar adalah untuk menentukan kelayakan dari isi produk berdasarkan hasil rating dari rater yang sesuai dengan bidang kurikulum pembelajaran. Dengan asumsi setiap $\mathrm{n}$ rater memeriksa setiap item dan menyatakan c-category peringkat skala ordinal (mulai dari kategori 
yang paling rendah hingga kategori yang paling tinggi) berdasarkan hasil penilaiannya pada validitas isi dari aspek yang dinilai (Aiken, 1980).

Secara lebih spesifik, dua rater menguji kelayakan bahan ajar kurikulum pembelajaran berdasarkan indikator atau komponennya. Indikator bahan ajar yang digunakan untuk mengetahui kelayakan bahan ajar adalah (1) identitas bahan ajar, (2) kelayakan materi, (3) kebahasaan, (4) sajian dan (5) kegrafisan. Sehingga dapat dikatakan bahwa dalam pengembangan bahan ajar melakukan uji validitas isi sangat penting untuk mengetahui kelayakan produk bahan ajar yang dihasilkan.

Namun belum diketahui secara lebih lanjut mengenai hasil uji validitas pada bahan ajar kurikulum pembelajaran untuk pendidikan guru sekolah dasar. Oleh karena itu dilakukanlah penelitian dengan tujuan untuk mengetahui kevalidan dari bahan ajar kurikulum pembelajaran untuk pendidikan guru sekolah dasar agar dapat diterapkan dalam proses pembelajaran.

\section{Metode Penelitian}

Artikel ini merupakan bagian dari penelitian dan pengembangan model Borg \& Gall. Ada sepuluh langkah dalam penelitian dan pengembangan model Borg \& Gall yaitu, 1) mengumpulkan informasi dan penelitian pendahuluan, 2) melakukan perencanaan, 3) mengembangkan bentuk produk awal, 4) melakukan uji coba terbatas produk awal untuk menghasilkan produk utama, 5) melakukan revisi terhadap produk utama, 6) melakukan uji coba produk utama, 7) melakukan revisi terhadap produk utama untuk menghasilkan produk akhir, 8) melakukan uji coba lapangan produk final, 9) melakukan revisi terhadap produk final, dan 10) mendiseminasi dan mengimplementasikan produk (Gall et al., 2003). Kesepuluh langkah pada proses pengembangan produk Borg \& Gall dikelompokkan kedalam 3 kelompok yaitu studi pendahuluan, pengembangan serta pengujian dan diseminasi yang dapat dilihat pada Gambar 1.

\begin{tabular}{|c|c|}
\hline Studi Pendahuluan & Pengembangan \\
\hline $\begin{array}{l}\text { - Wawancara, dimaksudkan } \\
\text { untuk mengumpulkan data } \\
\text { bahan ajar kurikulum } \\
\text { pembelajaran } \\
\text { - Observasi, pengumpulan } \\
\text { data dilakukan dengan } \\
\text { pengamatan terhadap } \\
\text { dokumen yang ada serta } \\
\text { kegiatan pembelajaran di } \\
\text { kelas. } \\
\text { - Studi Pustaka.Pada tahap } \\
\text { ini dilakukan kegiatan } \\
\text { mengkaji dan mempelajari } \\
\text { konsep-konsep atau teori } \\
\text { yang berkaitan dengan } \\
\text { produk yang } \\
\text { dikembangkan. }\end{array}$ & $\begin{array}{l}\text { - Penyusunan produk awal, } \\
\text { didapat dari studi } \\
\text { pendahuluan dan mengacu } \\
\text { pada dasar-dasar teori yang } \\
\text { disimpulkan dari studi } \\
\text { kepustakaan, maka disusunlah } \\
\text { draf awal produk } \\
\text { Uji terbatas, draf bahan ajar } \\
\text { kurikulum pembelajaran yang } \\
\text { telah dirancang kemudian } \\
\text { direview oleh pakar ahli } \\
\text { materi dan validator ahli } \\
\text { media. (Tahap Validasi) } \\
\text { Uji Utama, dilakukan } \\
\text { bersama dengan praktisi } \\
\text { (guru) serta melibatkan } \\
\text { peserta didik dalam } \\
\text { penggunaan bahan ajar } \\
\text { kurikulum pembelajaran }\end{array}$ \\
\hline
\end{tabular}

Pengujian Dan Diseminasi

Pengujian efektivitas produk yang telah divalidasi dilakukan dengan pre-eksperimen, yaitu membandingkan efektivitas mengajar menggunakan bahan ajar kurikulum pembelajaran dengan bahan ajar kurikulum pembelajaran (yang sudah dikembangkan). $\mathrm{Hal}$ ini dapat dilihat hasil dari perbandingan antara hasil pretes dan post tes setelah menggunakan produk yang dikembangkan

Gambar 1. Bagan Alur Penelitian Pengembangan Bahan Ajar Kurikulum Pembelajaran 
Berdasarkan gambar 1 uji validitas masuk pada tahap uji terbatas. Terdapat berbagai cara untuk menguji validitas isi namun jenis uji validitas isi yang digunakan dalam penelitian pengembangan bahan ajar kurikulum pembelajaran untuk pendidikan guru sekolah dasar adalah Aiken's V. Indeks Aiken V merupakan indeks kesepakatan rater terhadap kesesuaian butir (atau sesuai tidaknya butir) dengan indikator yang ingin diukur menggunakan butir tersebut (Retnawati, 2016). Nilai koefisien Aiken's V berkisar antara 0 - 1. Rumus statistik Aiken's V adalah sebagai berikut:

$$
\begin{aligned}
& \mathrm{V}=\sum \mathrm{s} /[\mathrm{n}(\mathrm{c}-1)] \\
& \mathrm{s}=\mathrm{r}-\mathrm{lo} \quad \text { (Azwar, 2014). }
\end{aligned}
$$

Teknik analisis data untuk kelayakan perangkat pembelajaran dilakukan dengan mentabulasi seluruh data yang diperoleh dari validator untuk setiap komponen dan butir penilaian yang tersedia dalam instrumen penilaian. Indikator bahan ajar yang dinilai adalah identitas bahan ajar, kelayakan materi, kebahasaan, sajian serta kegrafisan. Yang dapat disajikan dalam tabel berikut

Tabel 1. Indikator Penilaian Bahan Ajar Kurikulum Pembelajaran Untuk Pendidikan Guru

\begin{tabular}{|c|c|c|}
\hline NO & Indikator & Pernyataan \\
\hline 1 & Identitas Bahan Ajar & 1. Kejelasan identitas bahan ajar \\
\hline \multirow[t]{5}{*}{2} & Kelayakan materi & 2. Kesesuaian materi dengan kebutuhan siswa \\
\hline & & 3. Kesesuaian materi dengan kebutuhan bahan ajar \\
\hline & & 4. Kebenaran substansi materi \\
\hline & & $\begin{array}{l}\text { 5. Manfaat untuk penambahan wawasan dan } \\
\text { pengetahuan }\end{array}$ \\
\hline & & 6. Kesesuaian materi dengan pembelajaran \\
\hline \multirow[t]{4}{*}{3} & Kebahasaan & 7. Keterbacaan \\
\hline & & 8. Kejelasan informasi \\
\hline & & 9. Kesesuaian dengan kaidah bahasa \\
\hline & & 10. Penggunaan bahasa secara efektif dan efektif \\
\hline \multirow[t]{4}{*}{4} & Sajian & 11. Urutan penyajian \\
\hline & & 12. Pemberian motivasi \\
\hline & & 13. Interaktivitas (stimulus dan respon) \\
\hline & & 14. Kelengkapan informasi \\
\hline \multirow[t]{2}{*}{5} & Kegrafisan & 15. Penggunaan font (jenis dan ukuran \\
\hline & & 16. Ilustrasi grafis, gambar dan foto \\
\hline
\end{tabular}
Sekolah Dasar

Validator yang dilibatkan adalah ahli materi yaitu Ndaru Mukti Oktaviani, M.Pd dan ahli media yaitu Yogi Kuncoro Adi, M.Pd. Penentuan jumlah expert judgement pada penelitian pengembangan bahan ajar kurikulum pembelajaran untuk pendidikan guru sekolah dasar didasarkan pada pernyataan bahwa untuk mengukur validitas isi, dua penilai diperlukan agar hasil ukur setiap aitem dapat digunakan untuk mendefinisikan sifat dan seluruh aitem yang mewakili semua aspek dari sifat yang tengah diukur (Yaghmale, 2003). Oleh karena itu jika uji validitas isi yang digunakan adalah Aiken's V, maka tidak menyalahi jumlah rater minimum yang harus digunakan.

\section{Hasil dan Pembahasan}

Pengembangan bahan ajar kurikulum pembelajaran untuk pendidikan guru sekolah dasar merupakan salah satu cara merespon perubahan dan kebutuhan dari mahasiswa. Hal ini dikarenakan struktur kurikulum selalu berkembang, maka materi perkuliahan kajian dan pengembangan kurikulum ini pun senantiasa berkembang sesuai situasi di lapangan (Nuryani, 
2010). Oleh karena itu, perlu dilakukan pengembangan bahan ajar kurikulum pembelajaran untuk pendidikan guru sekolah dasar agar pengetahuan yang diperoleh mahasiswa dapat digunakan sesuai dengan situasi lapangan.

Tahap pengembangan bahan ajar kurikulum pembelajaran untuk pendidikan guru sekolah dasar mengikuti langkah Borg \& Gall yang dikelompokkan kedalam 3 tahap. Tahap pertama adalah studi pendahuluan. Pada tahap ini dilakukan wawancara, observasi, dan studi pustaka. Tahap ini dilakukan untuk mengumpulkan informasi kebutuhan dari bahan ajar kurikulum pembelajaran untuk pendidikan guru sekolah dasar. Kegiatan pada tahap ini adalah melakukan penelitian pendahuluan berupa pengumpulan informasi tentang potensi dan permasalahan yang ada dilapangan (Firmansyah et al., 2020). Perlu diketahui bahwa melalui berbagai informasi yang dikumpulkan dapat digunakan sebagai bahan untuk merencanakan produk tertentu yang diharapkan dapat mengatasi kebutuhan (Sugiyono, 2014).

Tahap kedua adalah pengembangan yang didalamnya terdapat penyusunan produk awal, uji terbatas, serta uji utama. Penyusunan produk awal dilakukan dengan mempertimbangkan hasil dari studi pendahuluan. Draf bahan ajar kurikulum pembelajaran untuk pendidikan guru sekolah dasar yang dikembangkan oleh peneliti adalah bahan ajar yang dikembangkan dengan mengacu pada tahap-tahap pengembangan yang telah dipaparkan pada bagian sebelumnya dan disesuaikan dengan teori yang mendukung. Bahan ajar yang dikembangkan berupa buku yang di dalamnya terdapat materi-materi mengenai kurikulum pembelajaran.

Selanjutnya dilakukan uji tebatas dengan melakukan uji validitas. Hal ini dilakukan karena pada penelitian pengembangan bahan ajar kurikulum pembelajaran untuk pendidikan guru sekolah dasar dalam pelaksanaannya membutuhkan uji kelayakan. Uji validitas dilakukan untuk memastikan bahwa produk bahan ajar yang dihasilkan layak digunakan. Salah satu cara untuk menguji kelayakan produk dapat ditempuh dengan menguji validitas isi.

Pada jenis penelitian pengembangan suatu produk, validitas isi memiliki peranan penting. Hal ini dikarenakan validitas isi merupakan validitas yang diestimasi lewat pengujian terhadap kelayakan atau relevansi isi tes/ produk melalui analisis rasional oleh panel yang berkompeten atau melalui expert judgement (Hendryadi, 2017). Dengan demikian, melalui validitas isi, produk yang dikembangkan akan dipastikan telah memadai dan mewakili konsep yang tengah dikembangkan. Begitu juga dalam penelitian pengembangan bahan ajar kurikulum pembelajaran untuk pendidikan guru sekolah dasar. Penilaian produk dilakukan oleh ahli (expert judgment) dengan cara melakukan penilaian terhadap produk bahan ajar kurikulum pembelajaran untuk pendidikan guru sekolah dasar. Bahan ajar kurikulum pembelajaran untuk pendidikan guru sekolah dasar dinilai oleh validator ahli untuk memperoleh data kelayakan produk yang dikembangkan

Jenis validitas isi yang dipilih adalah Aiken's V . Hal ini disebabkan berdasarkan tabel Aiken's V dapat diketahui bahwa jumlah rater minimun dalam Aiken's V adalah 2 sedangkan rater maksimumnya adalah 25 (Aiken, 1985). Hal ini bersesuaian dengan jumlah expert judgement yang digunakan dalam penelitian pengembangan bahan ajar kurikulum pembelajaran untuk pendidikan guru sekolah dasar yaitu 2 orang ahli meliputi ahli materi dan ahli media yang akan menerapkan bahan ajar kurikulum pembelajaran untuk pendidikan guru sekolah dasar.

Produk ini diuji validitas oleh dua validator. Validator yang dilibatkan adalah ahli materi yaitu Ndaru Mukti Oktaviani, M.Pd dan ahli media yaitu Yogi Kuncoro Adi, M.Pd. Validator tersebut memberikan masukan dan menilai bahan ajar kurikulum pembelajaran 
untuk pendidikan guru sekolah dasar yang dikembangkan oleh peneliti. Kegiatan validasi dilakukan dengan cara memberikan bahan ajar kurikulum pembelajaran untuk pendidikan guru sekolah dasar beserta lembar penilaian kepada kedua validator ahli. Validasi dengan cara menyerahkan bahan ajar kurikulum pembelajaran untuk pendidikan guru sekolah dasar yang telah dikembangkan memudahkan peneliti untuk mendapatkan masukan atau saran baik secara lisan maupun tertulis dari kedua validator yang diperoleh dari hasil diskusi.

Berdasarkan hasil penilaian pada bahan ajar diperoleh skor 0.918 dimana skor ini berada pada rentang antara 0 sampai 1,00 maka skor Aiken's V tersebut dalam tabel validator dapat diinterpretasikan sebagai koefisien yang cukup tinggi bagi setiap indikator bahan ajar kurikulum pembelajaran untuk pendidikan guru sekolah dasar. Artinya setiap indikator yang terdapat dalam produk bahan ajar kurikulum pembelajaran untuk pendidikan guru sekolah dasar memiliki validitas isi yang baik. Hasil uji kelayakan produk bahan ajar kurikulum pembelajaran untuk pendidikan guru sekolah dasar pada setiap indikator dapat disajikan dalam tabel berikut:

Tabel 2. Hasil Uji Aiken's V produk bahan ajar kurikulum pembelajaran untuk pendidikan guru sekolah dasar

\begin{tabular}{llcc}
\hline No & \multicolumn{1}{c}{ Indikator } & Indeks Aiken's V & Kategori \\
\hline 1 & Identitas Bahan Ajar & 1 & Validitas Tinggi \\
2 & Kelayakan materi & 0,875 & Validitas Tinggi \\
3 & Kebahasaan & 0,906 & Validitas Tinggi \\
4 & Sajian & 0,875 & Validitas Tinggi \\
5 & Kegrafisan & 0,937 & Validitas Tinggi \\
\hline
\end{tabular}

Berdasarkan tabel 2 maka dapat dapat diketahui skor Aiken's V pada masing-masing indikator. Pada indikator identitas bahan ajar diperoleh angka 1 yang artinya dapat diinterpretasikan bahwa aitem memiliki koefisien yang tinggi. Pada indikator kelayakan materi diperoleh angka 0,875 yang dapat diinterpretasikan bahwa aitem memiliki koefisien yang tinggi. Selain itu pada indikator kebahasaan diperoleh angka 0,906 yang dapat diinterpretasikan bahwa aitem memiliki koefisien yang tinggi.

Pada indikator sajian diperoleh angka 0,875 yang dapat diinterpretasikan bahwa aitem memiliki koefisien yang tinggi, dan pada indikator kegrafisan sebagai indikator terakhir diperoleh angka 0,937 yang dapat diinterpretasikan bahwa aitem memiliki koefisien yang tinggi. Sehingga dapat dikatakan bahwa seluruh aitem memiliki koefisien yang tinggi.

Dari seluruh angka Aiken's V setiap indikator paling rendah mendapat angka 0,875 pada indikator kelayakan materi dan sajian dari bahan ajar. Sedangkan indikator yang mendapatkan skor paling tinggi adalah identitas bahan ajar yang mendapatkan skor 1. Oleh karena itu dapat dikatakan bahwa keseluruh aitem tersebut memiliki validitas isi yang baik dan mendukung validitas isi secara keseluruhan.

Setelah melakukan validitas melalui expert judgement maka bahan ajar kurikulum pembelajaran untuk pendidikan guru sekolah dasar dikatakan valid. Hasil penelitian ini bersesuaian dengan pendapat (Ibrahim et al., 2020) yang menyatakan bahwa semua perangkat pembelajaran yang divalidasi oleh ahli tergolong valid. Oleh karena itu apabila bahan ajar kurikulum pembelajaran untuk pendidikan guru sekolah dasar pada pelaksanaan uji validitas menggunakan Aiken's V dimana pada proses validasinya melibatkan expert judgement sebagaimana yang telah dilakukan, maka bahan ajar tersebut dapat dinyatakan valid.

Selain berdasarkan skor Aiken's V terdapat beberapa masukan dari kedua validator. Masukan pertama adalah penambahan chart pada bab model pengembangan kurikulum. 
Chart digunakan sebagai ilustrasi proses dan langkah pengembangan kurikulum sehingga mahasiswa lebih mudah dalam membangun pemahaman mengenai proses pengembangan kurikulum. Hal ini bersesuaian dengan pendapat (Gilang et al., 2017) yang menyatakan bahwa bahan ajar dengan ilustrasi yang memadai akan mempengaruhi proses dan pola pikir. Masukan kedua adalah pada penulisan huruf kapital agar lebih dirapikan lagi. Semua masukan ini dijadikan bahan perbaikan oleh peneliti mengenai produk bahan ajar kurikulum pembelajaran untuk pendidikan guru sekolah dasar.

Setelah melakukan uji terbatas maka langkah selanjutnya adalah melakukan uji utama. Pada uji utama produk yang dinyatakan valid akan digunakan pada mahasiswa dan pada langkah terakhir adalah melakukan diseminasi. Artinya produk bahan ajar kurikulum pembelajaran untuk pendidikan guru sekolah dasar dapat digunakan oleh khalayak umum dan tetap dilakukan pengecekan akan dampak penggunaan bahan ajar kurikulum pembelajaran untuk pendidikan guru sekolah dasar.

\section{Kesimpulan}

Berdasarkan hasil dan pembahasan maka dapat disimpulkan bahwa hasil analisis Aiken's $\mathrm{V}$ diperoleh skor 0,918 , dan diinterpretasikan sebagai koefisien yang cukup tinggi karena skor tersebut ada diantara 0 sampai 1,00. Sehingga bahan ajar kurikulum pembelajaran untuk pendidikan guru sekolah dasar dalam kategori valid. Keterbatasan penelitian ini adalah hanya berfokus pada penentuan validitas dari bahan ajar kurikulum pembelajaran untuk pendidikan guru sekolah dasar. Sehingga perlu dilakukan langkah selanjutnya setelah bahan ajar kurikulum pembelajaran untuk pendidikan guru sekolah dasar dinyatakan valid yaitu melakukan perbaikan sesuai dengan masukan dari validator serta selanjutnya dapat dilakukan uji utama dan diseminasi.

\section{Daftar Pustaka}

Aiken, L. R. (1980). Content Validity and Reliability of Single Items or Questionnaires. Educational and Psychological Measurement, 40(4), 955-959. https://doi.org/10.1177/001316448004000419

Aiken, L. R. (1985). Three Coefficients for Analyzing the Reliability and Validity of Ratings. Educational and Psychological Measurement, 45(1), 131-142. https://doi.org/10.1177/0013164485451012

Azwar, S. (2014). Reliabilitas dan Validitas. Pustaka Belajar.

Buyung, B. (2018). Pengembangan Bahan Ajar pada Mata Kuliah Belajar dan Pembelajaran di Fakultas Keguruan dan Ilmu Pendidikan Universitas Batanghari Jambi. Jurnal Ilmiah Universitas Batanghari Jambi, 18(3), 509-517. https://doi.org/10.33087/jiubj.v18i3.517

Devi, P. (2009). Pengembangan Perangkat Pembelajaran Untuk Guru SMP. PPPPTK IPA.

Firmansyah, F., Purwati, P., Siregar, N. N., \& Irnandi, I. (2020). Integrasi Pendidikan Karakter Rasa Ingin Tahu Pada Pengembangan Bahan Ajar Matematika SD. Jurnal Cakrawala Pendas, 6(2), 143-155. https://doi.org/10.31949/jcp.v6i2.2211

Gall, M. D., Gall, J. P., \& Borg, W. (2003). Educational Research: An Introduction (7th Edition). Pearson Education.

Gilang, L., Sihombing, R. M., \& Sari, N. (2017). KESESUAIAN KONTEKS DAN ILUSTRASI PADA BUKU BERGAMBAR UNTUK MENDIDIK KARAKTER ANAK USIA DINI. Jurnal Pendidikan Karakter, 7(2), 158-169.

Haynes, S. N., Richard, D. C. S., \& Kubany, E. S. (1995). Content validity in psychological assessment: A functional approach to concepts and methods. Psychological Assessment, $7(3), 238-247$. 
Hendryadi, H. (2017). Validitas Isi: Tahap Awal Pengembangan Kuesioner. Jurnal Riset Manajemen Dan Bisnis (JRMB) Fakultas Ekonomi UNIAT, 2(2), 169-178. https://doi.org/10.36226/jrmb.v2i2.47

Ibrahim, I., Gunawan, G., \& Kosim, K. (2020). Validitas Perangkat Pembelajaran Fisika Berbasis Model Discovery dengan Pendekatan Konflik Kognitif. Jurnal Pijar Mipa, 15(3), 214. https://doi.org/10.29303/jpm.v15i3.1878

Kurniawan, W., Pujaningsih, F. B., Alrizal, A., \& Latifah, N. A. (2018). Analisis Kebutuhan Mahasiswa Terhadap Bahan Ajar Sebagai Acuan Pengembangan Modul Fisika Gelombang Bola Dan Tabung. EduFisika, 3(01), 17-25. https://doi.org/10.22437/edufisika.v3i01.5805

Nuryani, W. (2010). Bahan Ajar Mata Kuliah Kajian dan Pengembangan Kurikulum. Pendidikan Seni Tari Fakultas Bahasa dan Seni.

Oktaviani, N. M., \& Wulandari, I. (2019). IMPLEMENTASI STANDAR PROSES DALAM KURIKULUM 2013 DI SEKOLAH DASAR. Primary: Jurnal Pendidikan Guru Sekolah Dasar, 8(2). https://doi.org/10.33578/jpfkip.v8i2.7960

Prastowo, A. (2013). Panduan Kreatif Membuat Bahan Ajar Inovatif. Diva Press.

Purwati, D., \& Suhirman. (2017). Pengembangan Bahan Ajar Perkuliahan Apresiasi Sastra Anak Berbasis Sugesti-Imajinatif Untuk Mengoptimalkan Budaya Menulis Mahasiswa Pada Program Studi Pendidikan Guru Sekolah Dasar (Pgsd). Jurnal Ilmiah Mandala Education, 3(1), 166-174.

Retnawati, H. (2016). Analisis Kuantitatif Instrumen Penelitian. Parama Publishing.

Sugiyono. (2014). Metode Penelitian Pendidikan Pendekatan Kuantitatif, Kualitatif, dan R\&D. Alfabeta.

Taherdoost, H. (2016). Validity and Reliability of the Research Instrument; How to Test the Validation of a Questionnaire/Survey in a Research. International Journal of Academic Research in Management (IJARM), 5(3), 28-36. https://doi.org/10.2139/ssrn.3205040

Ulfah, A., \& Jumaiyah. (2018). Jurnal Inovasi Pendidikan PENGEMBANGAN BAHAN AJAR MATA KULIAH BAHASA INDONESIA. Jurnal Inovasi Pendidikan, 2(2), 1-9.

Vakili, M. M., Jahangiri, N., \& and. (2018). Content Validity and Reliability of the Measurement Tools in Educational, Behavioral, and Health Sciences Research. Journal of Medical Education Development, 10(28), 106-118. https://doi.org/10.29252/edcj.10.28.106

Yaghmale, F. (2003). Content validity and its estimation. Journal of Medical Education, 3(1), 25-27. https://doi.org/10.22037/jme.v3i1.870 